Original Article

\title{
Seven species of Labidocera (Copepoda, Calanoida, Pontellidae) from off Kenjeran, Surabaya, Indonesia
}

\author{
Mulyadi*, Dewi Citra Murniati \\ Research Center for Biology, Indonesian Institute of Sciences (LIPI)
}

\begin{abstract}
During taxonomic studies on the pelagic copepods of the Indonesian waters, seven species of Labidocera were identified from off Kenjeran, Surabaya during 1994-2012. Four of these species, L. acuta (Dana, 1849), L. kroyeri (Brady, 1883), L. laevidentata ((Brady, 1883), and L. minuta (Giesbrecht, 1889) have been recorded previously, L. javaensis (Mulyadi, 1997) has been described as new species, and two species, L. bengalensis (Krishnaswamy, 1952) and L. sinilobata (Shen \& Lee, 1963) were new records for Indonesian waters. Labidocera bengalensis and L. minuta belong to the L. minuta-group, $L$. kröyeri to the L. kröyeri-group, L. javaensis to the L.pectinata-group, $L$. sinilobata to the $L$. detruncata-group, while $L$. acuta and $L$. laevidentata to the unassigned-group. The number of species were highest in June 1994 and June 1998 , each with 5 recorded species. The number of species were decreased, 3 species in November 2000, 1 species in October 2010 and 2 species in July 2012. Labidocera sinilobata has been found for all times sampling, L. javaensis for four times, L. acuta and L. kroyeri are found twice, and L. bengalensis L. laevidentata and L. minuta are found for one time sampling. Descriptions, measurements and figures are given for these species, along with a review of their distribution over the world's oceans, and with taxonomic remarks, ecological notes, their species groups, and restricted synonyms.
\end{abstract}

Keywords: Copepods, Labidocera, taxonomy, zoogeography

Received: 09 February 2018 Revised: 09 May 2018 Accepted: 20 October 2018

\section{Introduction}

The genus Labidocera Lubbock, 1853 is known to be abundant and species-rich in the Indo-Australian region. Most Labidocera species are restricted to waters ranging from warm-temperate to tropical. The biogeographical distribution of the genus is intriguing and can be used as a biological indicator of water masses, inshore-offshore boundaries, and divisions between zoogeographical regions (Fleminger, 1967; Fleminger \& Moore, 1977; Fleminger et al. 1982; Sherman, 1963, 1964; Veronina, 1962). Most members of the genus Labidocera are found day and night in the surface layer usually beneath the neuston, to a depth of about 10-15 m.

Currently, the genus Labidocera comprises 59 known species (see, e.g., Walter \& Boxshall, 2013; Mulyadi, 2014). Of these, 15 species have been reported from Indonesian waters (Scott, 1909; Fleminger et al. 1982; Mulyadi, 1997, 2014). The recorded species are: L. acuta Dana, 1849; L. bataviae A. Scott, 1909; L. detruncata Dana, 1849; L. kröyeri (Brady, 1883); L. laevidentata (Brady, 1883); L. madurae A. Scott, 1909; L. minuta Giesbrecht, 1889; L. papuensis Fleminger et al., 1982; L. pavo Giesbrecht, 1889. Three species L. javaensis Mulyadi, 1997; L. muranoi Mulyadi, 1997; and L. kaimanaensis Mulyadi, 2014, have been described as new species, while 2 other species, i.e., L. bengalensis Krishnaswamy, 1952; L. sinilobata Shen \& Lee, 1963; and $L$. rotunda Mori, 1929, represent new records for the area. These species are divided into five species-groups

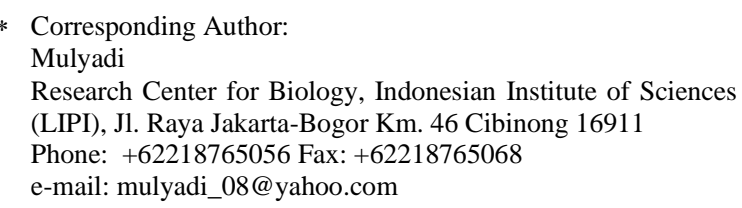

based on morphological characters. Labidocera dentruncata-group (cf. Fleminger, 1967) includes $L$. bataviae A. Scott, 1909; L. detruncata (Dana, 1849); L. madurae (Scott, 1909); L. pavo Giesbrecht, 1889; and $L$. sinilobata Shen \& Lee, 1963. Labidocera kröyeri-group (cf. Fleminger, 1967) includes L. kröyeri (Brady, 1883); and L. muranoi Mulyadi, 1997. Labidocera minuta-group (cf. Mulyadi, 1997) includes L. bengalensis Krishnaswamy, 1952; and L, minuta Giesbrecht, 1889. Labidocera pectinata-group (cf. Fleminger et al., 1982) includes L. javaensis Mulyadi, 1997; L. papuensis Fleminger et al. 1982; and L. rotunda Mori, 1929. Unassigned-group (cf. Mulyadi, 1997) includes L. acuta Dana, 1849; and L. laevidentata (Scott, 1909; Fleminger et al., 1982; Mulyadi, 1997).

Scott's (1909) reported seven species of Labidocera collected in Indonesian waters during the Siboga Expedition (1899-1900), is undoubtedly the most important paper on the genus in the region. However, the author did not provide figures or adequate descriptions of most of the species caught. Also, there are some misidentifications, doubtful records, and synonyms, which need to be studied more accurately.

This paper deals with descriptions and illustrations of seven species of Labidocera collected from off Kenjeran, Surabaya. The text further aims at clarifying some synonymy, and discusses the species groups and their regional distribution pattern.

\section{Methods}

Zooplankton samples were collected from off Kenjeran, Surabaya during 1994-2012 (Tab. 1). Sampling was done by the author and included surface towing and vertical hauls from $5 \mathrm{~m}$ and $10 \mathrm{~m}$ depth to the surface with a conical plankton net (mesh size $0.33 \mathrm{~mm}$, mouth diameter $0.45 \mathrm{~m}$ ). All samples were fixed and preserved 
in 5\% buffered formaldehyde/sea water. Labidocera specimens were sorted from the original samples, dissected with needles in $10 \%$ glycerol/distilled water under a stereo microscope, and the body and appendages were observed under a compound microscope and illustrated with the aid of a camera lucida. The morphological terminology follows Huys \& Boxshall (1991). The prosome length was measured from the anterior apex to the mid-posterior end of the prosome, and the urosome length from the mid-anterior end of urosome to the posterior end of the caudal ramus excluding the distal setae. The lengths and widths of urosomal somites were measured with a calibrated ocular micrometer

Abbreviation used in the text are: TL, total length; A1, antennule; A2, antenna; Pdg1-Pdg5, pedigerous somites 1-5; P1-P5, swimming legs 1-5; Ur1-Ur5, urosomal somites 1-5; CR, caudal ramus/i; B1, coxa, B2, basis; Re1-Re3, exopodal segments 1-3; Ri1-Ri3, endopodal segments 1-3; Se, outer spine; $\mathrm{Si}$, inner spine; St, terminal spine. The type-specimens are formalin-preserved and deposited at the Museum Zoologicum Bogoriense (MZB), Research Center for Biology, Indonesian Institute of Sciences (LIPI), Cibinong, Indonesia. A total seven species of Labidocera were found during the study, including L. acuta, L. bengalensis Krishnaswamy, $L$. javaensis, L. kröyeri, $L$. minuta Giesbrecht, $L$. laevidentata and L. sinilobata Shen \& Lee (Tabel 2). Among these species, L. javaensis described as new species by Mulaydi (1997). The other four species, $L$. acuta, L. kröyeri, L. minuta Giesbrechtand L. laevidentata have been recorded from Indonesian waters by previous expedition reports. Further two known species, $L$. bengalensis and $L$. sinilobata have been recorded for the first time from this area. The geographical span of each species are summarized in table 2 .

Table 1. Sampling sites, dates of sampling and water conditions.

\begin{tabular}{|c|c|c|c|}
\hline Sites & Sampling dates & Time of sampling & Water conditions \\
\hline \multirow[t]{5}{*}{ Off Kenjeran, Surabaya } & 8-9 June 1994 & $06.00 \mathrm{am}$ & High tide, $6.0 \mathrm{~m}$ depth \\
\hline & 2 June 1998 & $07.10 \mathrm{am}$ & High tide, $5.0 \mathrm{~m}$ depth \\
\hline & 10 November 2000 & $03.30 \mathrm{pm}$ & $\begin{array}{l}\text { Low tide, } 1.0-1.5 \mathrm{~m} \text { depth, the waters } \\
\text { was shallow and turbid. }\end{array}$ \\
\hline & 10 October 2010 & $05.30 \mathrm{pm}$ & $\begin{array}{l}\text { Low tide, } 0.5-1.0 \mathrm{~m} \text { depth, the waters } \\
\text { was shallow and turbid. }\end{array}$ \\
\hline & 13 July 2012 & $05.00 \mathrm{pm}$ & $\begin{array}{l}\text { Low tide, } 0.5 \mathrm{~m} \text { depth, the waters was } \\
\text { shallow and turbid. }\end{array}$ \\
\hline
\end{tabular}

Table 2. Species list of Labidocera recorded in the present study, their sampling sites and their previous records in Indonesian waters, neighbouring areas and the major oceans, $\bullet=$ present records, $\mathrm{o}=$ previous records, $\mathrm{Nr}=\mathrm{New}$ records, $\mathrm{A}=$ Indonesian waters, $\mathrm{B}=\mathrm{Malacca}$ Strait, $\mathrm{C}=\mathrm{South} \mathrm{China}$ Sea, D = Australian waters, I, P and At = Indian, Pacific and Atlantic Oceans.

\begin{tabular}{|c|c|c|c|c|c|c|c|c|c|c|c|c|c|}
\hline \multirow{3}{*}{ Species } & \multicolumn{5}{|c|}{ Sampling dates } & \multicolumn{4}{|c|}{ Neighbouring areas } & \multicolumn{3}{|c|}{ Oceans } & \multirow{3}{*}{ Notes } \\
\hline & & & & & & $\mathrm{A}$ & B & $\mathrm{C}$ & $\mathrm{D}$ & $\mathrm{I}$ & $\mathrm{P}$ & At & \\
\hline & 1994 & 1998 & 2000 & 2010 & 2012 & & & & & & & & \\
\hline L. acuta & & $\bullet$ & $\bullet$ & & & 0 & 0 & 0 & $\circ$ & 0 & o & & $\mathrm{N}-\mathrm{O}$ \\
\hline L. bengalensis & $\bullet$ & & & & & $\mathrm{Nr}$ & $\circ$ & & & ० & & & $\mathrm{N}$ \\
\hline L. javaensis & $\bullet$ & $\bullet$ & $\bullet$ & & $\bullet$ & $\bullet$ & & & & & & & $\mathrm{N}$ \\
\hline L. kroyeri & $\bullet$ & $\bullet$ & & & & ० & $\circ$ & $\circ$ & $\circ$ & $\circ$ & $\circ$ & & $\mathrm{N}$ \\
\hline L. laevidentata & & $\bullet$ & & & & ० & $\circ$ & $\circ$ & $\circ$ & $\circ$ & $\circ$ & & $\mathrm{N}-\mathrm{O}$ \\
\hline L. minuta & $\bullet$ & & & & & $\circ$ & $\circ$ & $\circ$ & $\circ$ & $\circ$ & $\circ$ & & $\mathrm{N}$ \\
\hline L. sinilobata & $\bullet$ & $\bullet$ & $\bullet$ & $\bullet$ & $\bullet$ & $\mathrm{Nr}$ & & $\circ$ & & & & & $\mathrm{N}$ \\
\hline Total of species & 5 & 5 & 3 & 1 & 2 & 7 & 5 & 5 & 5 & 5 & 5 & & \\
\hline
\end{tabular}

\section{Results}

The number of species were highest in June 1994 ( $L$. bengalensis, L. javaensis, L. kroyeri, L. minuta, and $L$. sinilobata) and June 1998 (L. acuta, L. javaensis, L. kroyeri, L. laevidentata and $L$. sinilobata) each with 5 recorded species. The number of species decreased in November 2000, October 2010 and July 2012 samples. Three species (L. acuta, L. javaensis and L. sinilobata) in 2000, one species (L. sinilobata) in 2010, and 2 species (L. javaensis and L. sinilobata) in 2012 samples.
Among the Labidocera species occurred in this study, L. sinilobata and L. javaensis were common species. Most of the species, except $L$. sinilobata, were never abundant and the frequency of occurrence of many species is not clear. Many of the species appear to be chiefly neritic albeit also occurring rarely in oceanic waters. Labidocera sinilobata has been found for all times sampling (25 inds/L), and L. javaensis ( 8 inds/L) for four times sampling. Labidocera acuta and L. kroyeri are 
found twice, with less abundant, 2 females and 2 males, and 2 females and 1 male specimens were found from this site, respectively. Labidocera bengalensis (3 inds/L), L. laevidentata ( 2 inds/L), and L. minuta ( 2 ind/L) are found only for one time sampling. Labidocera bengalensis and L. minuta were found on June 1994, while L. laevidentata was found on June 1998.

All the species of Labidocera mentioned above were morphologically analyzed for the purpose of clarifying the geographical distribution patterns (Table 2). The pattern of distribution differ for each species. Labidocera acuta, L. kröyeri, L. laevidentata, and L. minuta $(57.14 \%)$ have been recorded in both Indian and Pacific Oceans. Labidocera bengalensis (14.28\%) was recorded only in the Indian Ocean, while L. sinilobata $(14.28 \%)$ has been recorded only in the China Seas (Silas \& Pillai, 1973; Krishnaswamy, 1952; Shen \& Lee, 1963). The remain one species, L. javaensis $(14.28 \%)$ has been described as new species, which has distribution range from the Java Sea to Kaimana Bay, West Papua (Mulyadi, unpubl.).

\section{Discussion}

Labidocera sinilobata is frequently occurred along the sampling periods in abundance ( 25 inds/L). Its presence in off Kenjeran is associated with high salinity and lowering temperature $\left(31 \mathrm{ppt}, 28^{\circ} \mathrm{C}\right)$. This species to be common in Indonesian waters from Jakarta Bay, off Kenjeran, and Flores Sea (Mulyadi. Unpubl.). According to Shen \& Lee (1963) L. sinilobata was occurred in rare number in the East China Sea. This species was reported only once in literature. Labidocera. javaensis was occurred in rare number in this study. This species are frequent in coastal waters of Java Sea to Kaimana Bay, West Papua (Mulyadi unpubl.).

Based on their horizontal distribution and habitats, copepod are divided into 5 species-groups: oceanic, neritic-oceanic, neritic, estuarine-neritic, and estuarine (Kim, 1985; Madhupratap \& Haridas, 1986). According to these groups, more than half, $71.4 \%$ (5 species) of the present Labidocera are classified as neritic species, and $28,6 \%$ (two species L. acuta and L. laevidentata) are listed as neritic-oceanic species with preference to the high salinity waters.

The species of Labidocera comprise a somewhat heterogeneous assemblage. So far no complete review of the group based on the study of species from all the world has been made, and very little attempt has never been made to separate groups of related species. It will be shown, that there are several different groups of species each with a number of important features in common, which tend to constitute morphologically and also zoogeographically distinct groups. In the genus Labidocera, species and species-groups can be distinguished by the structure of the posterior corners of the last pedigerous somite, the genital compound somite, caudal rami, rostrum and fifth legs of both sexes (Fleminger et al., 1982, 1986; Mulyadi, 1997).

Fleminger et al. (1982) and Fleminger (1986) recognized 4 species-groups among the Indo-West Pacific Labidocera, i.e., the L. detruncata-group, the L. kroyerigroup and the L. pectinata-group, and yet to be assigned- group, but they did not give any definitions for these groups. By analyzing the characteristics of all these groups I still recognize one other new group. It is the $5^{\text {th }}$ group of Labidocera, the L. minuta-group. Therefore seven species of Labdocera found in off Kenjeran were divided into 4 Labidocera species-groups (detruncata-, kroyeri-, minuta-, pectinata-) as well as yet unassigned group. Two species, $L$. bengalensis and $L$. minuta belong to the L. minuta-group, L. javaensis to the L. pectinatagroup, $L$. kröyeri to the $L$. kröyeri-group, and $L$. sinilobata to the L. detruncata-group, while L. acuta and L. laevidentata to the unassigned-group.

Labidocera bengalensis and L. minuta belong to $L$. minuta-group (cf Mulyadi, 1997) in the female in having (i) the urosome consists of 3 somites, genital compound somite elongate, (ii) the exopod of $5^{\text {th }}$ legs long and slender, endopod pointed, and (iii) the posterior corners of prosome produced into rounded processes. The male is identified by (i) the thumb of chela of right $5^{\text {th }}$ leg short, broader towards it tip with 1 medial process, (ii) the right A1 with segment $\mathrm{XX}$ armed with villiform denticulated ridges. This group consists only two species, $L$. bengalensis and L. minuta. Labidocera bengalensis described by Krishnaswamy (1952) based on specimens collected from Madras coast. So far this species recorded from the type locality (Madras coast) and Java Sea. Labidocera minuta recorded from tropical and subtropical regions of Indo-West Pacific (Silas \& Pillai, 1973). Australian waters records were given by Greenwood (1979). In Indonesian waters were recorded by (Scott, 1909; Delsman, 1939; Mulyadi, 2002).

Labidocera javaensis belongs to the L. pectinatagroup (cf Fleminger et al., 1982) by sharing the following combination of characteristics: (i) presence of cephalic hooks in both sexes, (ii) female urosome consists of 3 somites, (iii) female fifth legs asymmetrical, with 2 lateral processes on $\mathrm{Re}, \mathrm{Ri}$ with many denticles on terminal and external margins, (iv) Re1 of male right fifth leg with stout, elongated thumb, inwardly curved, (v) $\operatorname{Re} 2$ of male left fifth leg with 2 stout, round-tipped spines and 2 aesthete-like setae. Fleminger et al. (1982) included five species in the 'pectinata' group: L. carpentariensis Fleminger et al. 1982, L. japonica Mori, 1935, L. papuensis Fleminger et al. 1982, L. pectinata Thompson \& Scott, 1903, and L. rotunda Mori, 1929, with $L$. javaensis Mulyadi, 1997 included, this group currently comprises six species. Labidocera javaensis is widely distributed in Indonesian waters from Java Sea to Kaimana Bay, West Papua, while L. papuensis is endemic to the Sorong Sea (Fleminger et al., 1982; Mulyadi, 2014). Labidocera carpentariensis is restricted to Gulf of Carpentaria and northern Arafura Sea, L. moretoni to eastern Australian waters, L. japonica to Japanese waters (Mori, 1937); and L. pectinata to coastal neritic waters of north-east Indian Sea. Fleminger (1986) records of the $L$. rotunda inhabiting coastal-neritic waters from southern Japan Sea to Java Sea is doubtful, because no L. rotunda specimen was obtained in Kenjeran (Java Sea) during this study. Labidocera rotunda recorded from Sebatik Island, North Kalimantan (Mulyadi. Unpubl.)

Published records of the $L$. kroyeri-group are restricted to inshore regions of tropical and subtropical 
areas between $35^{\circ} \mathrm{N}$ and $25^{\circ} \mathrm{S}$ and $70^{\circ} \mathrm{E}$ and $151^{\circ} \mathrm{E}$. Labidocera kroyeri is widely distributed within this area, however, the rest of the group seems to have relatively narrow distribution range, i.e., L. dakini Greenwood, 1978 from eastern Australian waters and Gulf of Carpentaria, L. gallensis Thompson \& Scott, 1903 and L. stylifera Thompson \& Scott, 1903 have only been recorded from the pheriphery of north-east Indian Sea. Labidocera muranoi Mulyadi, 1997 collected from Cilacap Bay, a mangrove estuary facing the Indian Ocean, may also have a narrow distribution range with preference to low salinity.

Labidocera sinilobata belongs to the L. detruncatagroup, which was established by Fleminger (1967) as a superspecies, by sharing the following characteristics: female urosome composed of 2 somites; female $5^{\text {th }}$ legs asymmetrical, with 3 lateral processes on exopod, endopod not furcated at apex, first exopodal segment of male right fifth leg with stout, elongated thumb and with blunt-tipped process near base of thumb; second exopodal segment of male left 5 th leg with long spine on posterior surface and 3 setae along distal margin. Currently, the $L$. detruncata-group comprises 16 known species, 5 of which (L. bataviae Scott, 1909; L. detruncata (Dana, 1849); L. gangetica Sewell, 1934; L. madurae Scott, 1909; L. pavo (Giesbrecht, 1889) are described in the tropical/subtropical waters of the Indo-West Pacific (Silas \& Pillai, 1973; Mulyadi, 2014). So far L. sinilobata Shen \& Lee, 1963 was only known from the type locality China Sea (Chen \& Zhang, 1965) extended to Java Sea,

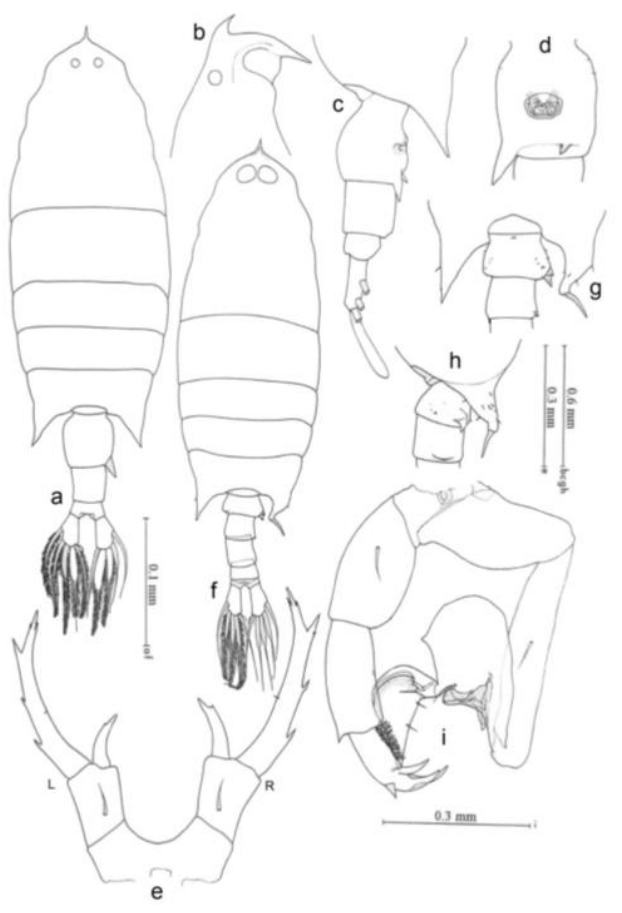

Figure 1. Labidocera acuta (Dana, 1849). Female, a, whole animal, dorsal view; b, cephalon, lateral view; c, Pdg5 and urosome, lateral view; d, genital double somite, dorsal view; e, fifth legs. Male, f, whole animal, dorsal view; g, Pdg5 and Ur1-Ur2, dorsal view; h, Pdg5 and Ur1-Ur2, lateral view; i, fifth legs particularly off Kenjeran, Surabaya (present records). Labidocera jaapari Othman, 1986 only known from the type locality, Malacca Strait, while L. kaimanaensis Mulyadi, 2014 described from Kaimana Bay, West Papua. Labidocera caudata Nicholls, 1944, L. cervi Kramer, 1895, L. farrani Greenwood \& Othman, 1979 and L. tasmanica Taw, 1974 were recorded only from the Australian region (Greenwood, 1979; Greenwood \& Othman, 1979). The remain 3 species: Labidocera nerii (Kroyer, 1849) is Atlantic species (Owre \& Foyo, 1967), whereas L. orsini and L. boxshalli were recorded from the Red Sea (El-Sherbiny, 1997; El-Sherbiny \& Ueda, 2010).

Labidocera acuta and L. laevidentata, are too diverse to be regarded as a species group. The differences occur in the position of cephalic hooks, the presence of median crest, segmentation of the first antenna, and the shape and armature of the terminal segment of the right male fifth leg, and so on. Labidocera acuta widely recorded from the tropical and subtropical neritic waters of Indo-Pacific (Silas \& Pillai, 1973), Australian waters, off New South Wales coast, Great Barrier Reef waters, and Moreton Bay (Dakin \& Colefax, 1940; Farran, 1936; Greenwood, 1979). Indo-Malayan region, frequently recorded as noted by (Scott, 1909; Delsman, 1939; and Othman \& Toda, 2006). Brady (1883) has described L. laevidentata based on a single male specimen collected off Sibago, Philippines. Scott (1909) transfered L. kroyeri var similis Wolfenden, 1906 to L. laevidentata.

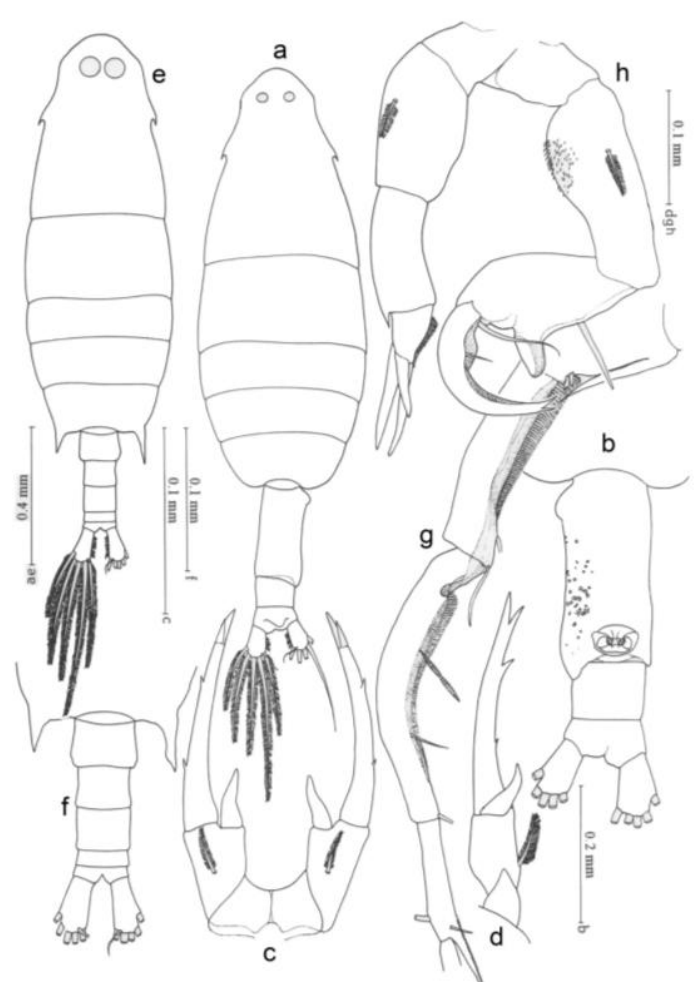

Figure 2. Labidocera bengalensis Krishnaswamy, 1952. Female, a, whole animal, dorsal view; b, Pdg5 and urosome, ventral view; c, fifth legs; d, left P5. Male, e, whole animal, dorsal view; f, Pdg5 and urosome, dorsal view; g, geniculate region of right $\mathrm{A} 1$; h, fifth legs. 
Labidocera acuta (Dana, 1849) (Fig. 1)Pontella acuta Dana, 1849: 30; Brady, 1883: 89, pl. 36, figs. 112.Labidocera acutum Giesbrecht, 1892: 445, pl. 23.Labidocera acuta, Giesbrecht \& Schmeil, 1898: 134; A. Scott, 1909: 164; Thompson \& Scott, 1903: 251; Farran, 1936: 116; Mori, 1937: 91; Wilson, 1950; Tanaka, 1964: 254; Chen \& Zhang, 1965, pl. 41; Silas \& Pillai, 1973: 346-364; Greenwood, 1979; Matsuo \& Marumo, 1982: 93; Othman et al. 1990: 564 Table 1; Othman \& Toda, 2006: 208-209.

Material examined.- Two females (3.20-3.25 mm), 1 male $(2.75 \mathrm{~mm})$ collected off Kenjeran, Surabaya by surface tow of $0.33 \mathrm{~mm}$ mesh plankton net at daytime on 2 June 1998

Female.- Prosome (Fig. 1a, b) cylindrical without lateral hooks; cephalosome and $\mathrm{Pdg} 1$ completely separated; Pdg4 and Pdg5 fused; posterior corners of prosome directed slightly outwards with acute triangular processes. Cephalosome with median crest and pair of small dorsal lenses; rostrum bifid, gap between rostral rami narrow. Urosome consists of 3 somites, asymmetrical, genital compound somite onion-shaped, with right posterolateral spine-like process; Ur2 as long as wide; anal somite very short; caudal rami asymmetrical, 1.7 times as long as wide, with 5 setae, of which $2^{\text {nd }}$ to $4^{\text {th }}$ caudal setae thickened proximally, enlarged portion of seta distinctly longer than ramus. Antennule symmetrical, 23 segmented; posterior margin of $2^{\text {nd }}-12^{\text {th }}$ segments fringed with fine hairs; ancestral segments II-IV and XXVII-XXVIII completely fused while VII-IX incompletely fused. Fusion pattern and setal formula as follows: I-3+ae (aesthetasc), II-IV-4+ae, V-2+ae, VI-2, VII-IX-6+2ae, X-2, XI-2+ae, XII-2, XIII-2+ae, XIV2+ae, XV-2+ae, XVI-2+ae, XVII-2+ae, XVIII-2+ae, XIX-2+ae, XX-2+ae, XXI-2+ae, XXII-1, XXIII-1, XXIV-1+1, XXV-1+1+ae, XXVI-2, XXVII-XXVIII4+ae, XXV-1+1+ae, XXVI-2, XXVII-XXVIII-4+ae. Fifth legs (Fig. 1e) asymmetrical, right leg longer, coxa and intercoxal sclerite completely fused; basis with outer seta; endopod spiniform; exopod uni segmented and elongate with 3 outer, 1 inner and 3 apical processes of which medial one longest; endopod bifurcated at apex.

Male.- Prosome more compact than female; dorsal lenses well-developed; cephalosome and Pdg1 completely separated; Pdg4 and Pdg5 fused; posterior corners of prosome asymmetrical, left side similar to female, right side produced into a curved process turned distolaterally and reaching posterior end of Ur2. Urosome consists of 5 somites, genital somite swollen laterally, asymmetrical, with small right posterolateral process; Ur3 longest; caudal rami asymmetrical, right ramus being larger, $2^{\text {nd }}$ to $4^{\text {th }}$ caudal setae thickened proximally.

Antennule geniculate on right side only, left one resembling that of female; right one indistinctly 15 segmented, posterior margin of $2^{\text {nd }}-5^{\text {th }}$ segments fringed with fine hairs; segment X, XI, and XXI-XXIII completely fused. Fusion pattern and setal formula as follows: I-3+ae, II-IV-4+ae, V-IX-10+3ae, X-XI-4+ae, XII-XIV-6+2ae, XVII-2+ae, XVIII-2+ae, XIX-1+p (hooked process) $+\mathrm{ae}, \mathrm{XX}-1+\mathrm{p}+\mathrm{ae}, \mathrm{XXI}-\mathrm{XXIII}-2+\mathrm{p}+\mathrm{ae}$, XXIV-1+1+p, XXV-1+1+ae, XXVI-2, XXVII-XXVIII$4+a e$. Segment XIX with proximal, anterior, triangular hooked process; segment XX with canoe-shaped tooth ridge which extends anterior of segment XIX; compound segments XXI-XXIII with tooth ridge extending to distal $1 / 3$ of segment XXIV; segment XXIV with lamelliform process. Fifth legs (Fig. 1i) uniramous, asymmetrical, coxa of right $5^{\text {th }}$ leg and intercoxal sclerite completely separated; basis with proximal outer seta, Re1 (chela) orbicular, Re2 (finger) short, broader medially, with 2 inner and 2 apical setae; coxa of left exopod coalesced into intercoxal sclerite, $\operatorname{Re} 1$ with small distolateral spine; $\mathrm{Re} 2$ ending in 3 finger-like processes, 1 small cresented basal process and 1 spine near distal end, inner margin hirsute.

Remarks: Labidocera acuta is easily identified by the median crest, the thickened $2^{\text {nd }}$ to $4^{\text {th }}$ caudal setae, and the form of P5 in both sexes. The female is identified by the stout distolateral spine on right side of Ur1, the right A1, the posterior corners of right Pdg5, and the pointed process on right side of Ur1 in the male. An oceanic cognate of $L$. acuta has been recently described as $L$. pseudacuta Silas \& Pillai, 1969.

Distribution: Recorded from the tropical and subtropical neritic waters of Indo-Pacific (Silas \& Pillai, 1973). Australian waters, off New South Wales coast (Dakin \& Colefax, 1933, 1940), Great Barrier Reef waters (Farran, 1936), Moreton Bay (Greenwood, 1979), Gulf of Carpentaria (Othman et al. 1990). Indo-Malayan region, frequently recorded as noted by Brady (1883), Scott (1909), Früchtl (1924), Delsman (1939), and Othman \& Toda (2006).

Labidocera bengalensis Krishnaswamy, 1952 (Fig. 2) Labidocera bengalensis Krishnaswamy, 1952: 321-323, fig. 1a-i (Type locality: Madras coast); Silas \& Pillai 1973: 802-803, fig. 13a-g; Othman et al. 1990: 564 Table 1; Othman \& Toda, 2006: 309-310, figs. 8-9.

Material examined.- Two females (1.45-1.50 mm), 1 male $(1.20 \mathrm{~mm})$ collected off Kenjeran Surabaya by surface tow of $0.33 \mathrm{~mm}$ mesh plankton net at daytime on 9 June 1994.

Female.- Prosome elongated; cephalosome and Pdg1 completely fused; Pdg4 and Pdg5 fused; posterior corners produced into asymmetrical rounded lobes. Cephalosome anteriorly rounded, with lateral hooks and small pair of dorsal lenses; rostrum bifid, widely spaced and distant from ventral ocellus. Urosome consist of 3 somites, genital compound somite asymmetrical, elongated, longer than Ur2, Ur3 and CR combined length, anterior and posterior parts of right side swollen, with a numbers of ventral papillae, lengthened posteriorly and covering anterior part of Ur2; Ur2 slightly produced posteriorly on right margin; Ur3 very short; caudal rami asymmetrical, left ramus longer and wider than right. Fifth legs symmetrical, exopod long, slender and bifurcate, 4 times as long as endopod, with 2 outer spinules, and 2 unequal processes at apex; endopod short, stout and pointed. Fusion pattern and setal formula of antennule same as those of L. acuta. Fifth leg (Fig. 2c) symmetrical, exopod long and slender, 4 times as long as endopod, with 2 outer spinules and 2 unequal apical processes; endopod short and pointed at apex.

Male.- Cephalon similar to female, dorsal eye lenses well-developed and in contact with each other. 
Cephalosome and Pdg1 separated; Pdg4 and Pdg5 fused; posterior corners of prosome produced into asymmetrical pointed processes, acutely pointed on left and blade-like on right side and longer than left. Urosome consists of 5 somites, without any processes; genital somite wider than long; caudal rami symmetrical. Fusion pattern and setal formula of antennules same as those of L. acuta. Segment XIX with elongated process lying parallel to anterior border of segment and extending to distal border of segment; segment XX and compound segments XXIXXIII each with tooted ridge; segment XXIV with spurlike process distally. Fifth legs (Fig. 2c) uniramous, asymmetrical; right basis with outer seta and patch of inner spinules; Re1 comprising palm, concave surface with 1 blunt process and 1 spiniform seta. $\operatorname{Re} 2$ bent inwards medially and with 1 marginal transparent flap, proximal inner margin with 1 long and 1 short seta at $1 / 3$ length of segment, and 2 subequal spines at apex. Left leg 4-segmented, Re1 with distolateral spine; Re2 with 3

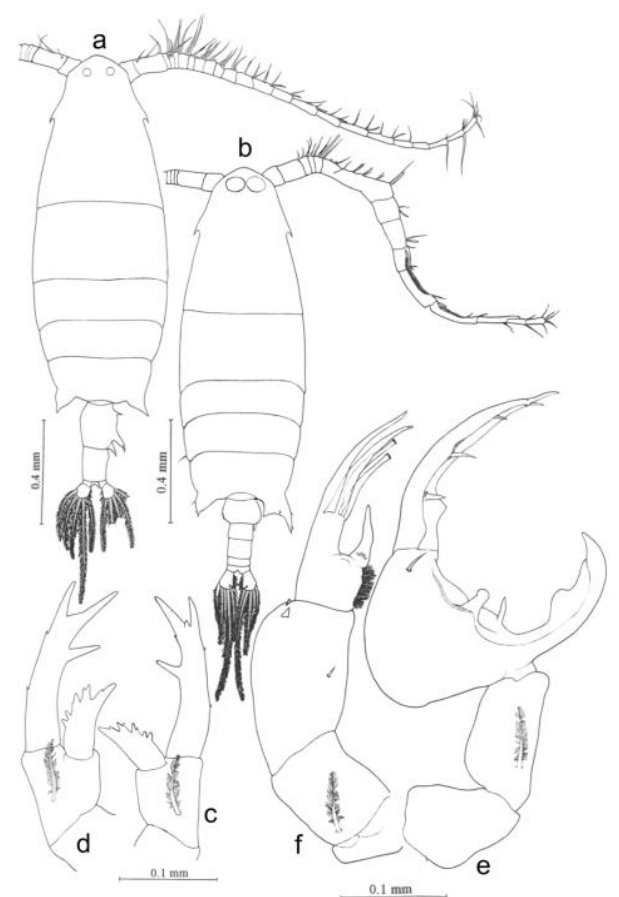

Figure 3. Labidocera javaensis Mulyadi, 1997. Female, a, whole animal, dorsal view; c, right P5; d, left P5. Male, b, whole animal, dorsal view; e, fifth legs.

Labidocera javaensis Mulyadi, 1997 (Fig. 3) Labidocera javaensis Mulyadi, 1997: 656-662, figs. 1-3 (Type locality: off Tegal, central Java, Indonesia).

Material examined.- Four females (1.90-2.10 mm), 3 males (1.75-1.80 mm) collected off Kenjeran, Surabaya by surface tow of $0.33 \mathrm{~mm}$ mesh plankton net at daytime on 2 June 1998.

Female.- Prosome cylindrical with lateral hooks; cephalosome and Pdg1 separated; Pdg4 and Pdg5 fused; posterior corners of prosome directed slightly outwards with asymmetrical acute triangular processes. Cephalosome rounded anteriorly with pair of dorsal lenses; rostrum bifid, gap between rostral rami narrow. Urosome consists of 3 somites; genital compound somite stout processes distally and 1 seta towards outer margin of inner process, inner margin hirsute.

Remarks.- Labidocera bengalensis described by Krishnaswamy (1952) from Madras coast obviously differs from the Indonesian specimens by the presence of outer spines on exopod of $5^{\text {th }}$ legs in the female; the presence of 3 distal processes on $2^{\text {nd }}$ exopod of left $5^{\text {th }}$ leg; and 1 plumose seta on 2 nd exopod of right $5^{\text {th }}$ leg in the male. Labidocera bengalensis is often mistaken for $L$. minuta in the general shape and size of both sexes. Female bengalensis have a much longer genital double somite and male minuta have a much longer right posterior corner process.

Distribution.- Labidocera bengalensis is an Indian Ocean species having first described from Madras coast, Andaman Sea (Silas \& Pillai, 1973), and Singapore waters (Othman \& Toda, 2006), and off Kenjeran, Java Sea (present records).

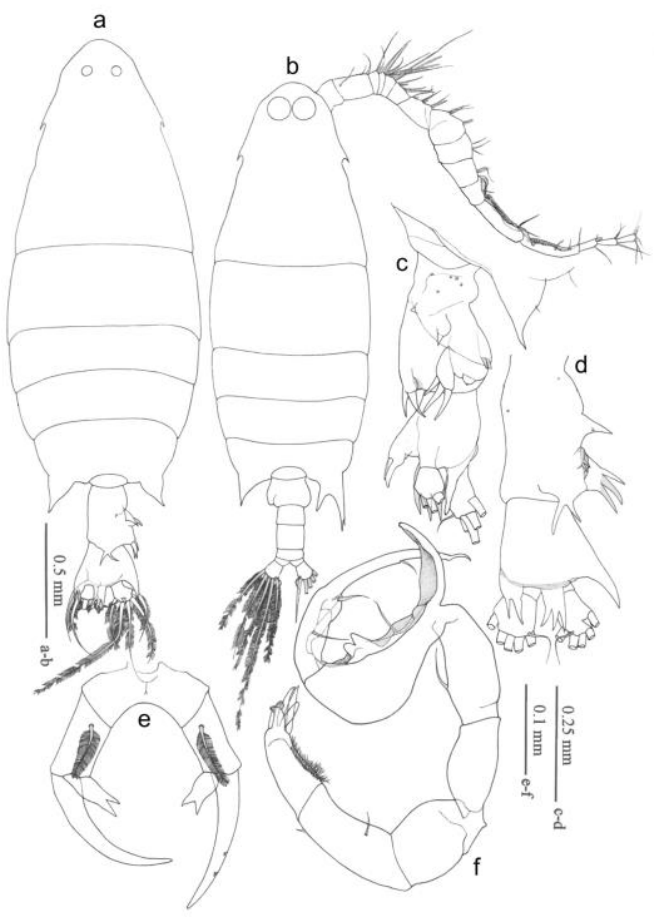

Figure 4. Labidocera kröyeri (Brady, 1883). Female, a, whole animal, dorsal view; c, Pdg5 and urosome, lateral view; d, urosome, dorsal view; e, fifth legs. Male, b, whole animal, dorsal view; f, fifth legs.

asymmetrical, longer than Ur2 and Ur3 combined length, right margin with 1 anterior and 2 posterior spines; Ur2 asymmetrical, anterior part of right margin with swelling; anal somite exceedingly short, only 0.1 as long as Ur1; caudal rami symmetrical, separated from Ur3 by articulation, 1.15 as long as wide.

Antennule symmetrical, 23-segmented, posterior margin of $2^{\text {nd }}-12^{\text {th }}$ segments fringed with fine hairs; ancestral segments II-IV and XXVII-XXVII completely fused while VII-IX incompletely fused. Fusion pattern and setal formula of antennule same as those of L. acuta. Fifth leg (Fig. 2c) symmetrical, right leg longer; coxa and intercoxal sclerite completely fused; basis with outer seta; endopod with many denticles on terminal and external 
margins; right Re with 2 outer spinules, 1 stout inner spine and 3 processes at apex, of which median process much smaller; Re of left leg with 2 outer spinules, 1 stout inner spine, and 2 processes at apex, of which the proximal process is larger.

Male.- Prosome more compact than female; dorsal lenses well-developed; cephalosome and Pdg1 separated; Pdg4 and Pdg5 fused; posterior corners of prosome asymmetrical with sharp triangular process on left side; right side bifurcate in dorsal view, trifurcate in lateral view armed with many spinules.

Urosome consists of 5 somites, genital somite swollen laterally; Ur3 longer than other somites, 1.8 as long as Ur4 and Ur5 combined length; caudal rami symmetrical, each ramus with 6 setae. Right antennules geniculate indistinctly 15 segmented. Posterior margin of $2^{\text {nd }}-5^{\text {th }}$ segments fringed with fine hairs; segments X, XI, and XII-XIV with incompletely formed arthropodal membranes, segments II-IV, XV and XVI, and XXIXXIII completely fused. Segments XIX with proximal, anterior, triangular hooked process; segment $\mathrm{XX}$ with canoe-shaped tooth ridge which extends proximally to middle of segment XIX; compound segments XXI-XXII with toothed ridge running from proximal fifth to distal third of its anterior border; segment XXIII prlolonged distally into spur-like process with pectinate anterior surface and extending to distal third of segment XXIV. Fifth legs (Fig. 3d) uniramous, asymmetrical, coxa of right $5^{\text {th }}$ leg and intercoxal sclerite completely separated; basis with outer seta; right $\operatorname{Re} 1$ broadened with convex inner margin, thumb curved inwards with pointed hook; outer surface of chela between thumb and distal end of Re1 with 1 stout process, 1 large anvil-shaped lamella and 1 small seta; Re2 curved outwards with 3 spines on concave surface and 2 unequal St. Left leg, Re1 broadly rectangular; $\operatorname{Re} 2$ about half as long as Re1, bulb-shaped, inner margin divided into 2 parts by strong projection extending beyond distal margin of segment, distal part narrowing abruptly just behind projection and unarmed, distal end with 2 stout, round-tipped spines and 2 aesthete-like setae, these spines and setae longer than their own segment.

Remarks: The female of $L$. javaensis distinguishable from all the species of L. pectinata-group by the presence 3 processes on right side, Ur2 without any processes on the right margin, $\mathrm{CR}$ without inner marginal protuberance, and the form of P5. The male is identified by the bifurcated right posterior corner, right side of Ur1 with distolateral spine, and the form of P5.

Labidocera kröyeri (Brady, 1883) (Fig. 4) Pontella kröyeri Brady, 1883: 93, figs. 1-19 (Type locality: Arafura Sea, Philippine). Labidocera kröyeri, Giesbrecht, 1892: 446; Sewell, 1932: 362; Chen \& Zhang, 1965, pl. 42, figs. 1-7; Greenwood, 1979: 99, fig. 3a-j.

Material examined.- Two females (2.05-2.10 mm), 1 males $(1.70 \mathrm{~mm})$ collected off Kenjeran, Surabaya by surface tow of $0.33 \mathrm{~mm}$ mesh plankton net at daytime on 8 June 1994

Female.- Prosome cylindrical with lateral hooks; cephalosome and Pdg1 separated; Pdg4 and Pdg5 fused; posterior corners of prosome directed slightly outwards with acute triangular processes. Cephalosome with pair of dorsal lenses; rostrum bifid, gap within rostral rami narrow. Urosome consists of 3 somites; genital compound somite asymmetrical, right margin with 2 processes, anterior one consist of 1 spine, posterior process consists of 2 sets of spines, $1^{\text {st }}$ set with 3 spines and 2 accessory minute spines, $2^{\text {nd }}$ set with 2 spines directed posteriorly. Ur2 produced into a robust triangular process extending from right lateral margin of somite, posteriorly somite extends over Ur3 and is produced on its distal margin into 5 sharp teeth in 2 sets, one set on its distal outer edge (2 spines), and another on its distomedial margin (3 teeth); anal somite very short; caudal rami symmetrical, caudal setae normal in shape. Fifth legs almost symmetrical, exopod robust, horn-shape, curved inwards with 3 minute Se; endopod slightly asymmetrical, curved distally, bifurcated at apex.

Antennule symmetrical, 23 segmented; posterior margin of $2^{\text {nd }}-12^{\text {th }}$ segments fringed with fines hairs; ancestral segments II-IV and XXVII-XXVIII completely fused while VII-IX incompletely fused. Fusion pattern and setal formula of antennule same as those of L. acuta. Fifth legs (Fig. 4d) uniramous, almost symmetrical, left leg longer than right; basis with outer seta; exopod hornshaped, curved inwards with 3 outer spinules; endopod bifurcate, inner process shorter.

Male.- Prosome slender; cephalosome and Pdg1 separated; Pdg4 and Pdg5 fused. Posterior corner of prosome asymmetrical; left corner with acute process; right corner with bifid processes and longer outer branch reaching distal border of Ur2. Cephalosome with lateral hooks and 2 large contiguous dorsal lenses. Urosome consists of 5 somites, genital somite asymmetrical, left side expanded; caudal rami symmetrical. Right A1 geniculate, indistinctly 14-segmented. Fusion pattern and setal formula of antennule same as those of L. acuta. Segment XIX with anterior crescentic process; segment XX and compound segments XXI-XXIII each with toothed ridge processing comb-like denticles; anterior margin of segment $\mathrm{XX}$ with tooth ridge which extends backs to middle of segment XIX; segment XXIV with prolonged distally directed, spur-like process distally.

Fifth legs (Fig. 4f) uniramous, asymmetrical, basis with outer seta; right exopod 2 segmented, Re1 comprising palm with medial bilobed process medially, 2 setae, and slender thumb; $\operatorname{Re} 2$ elongate, finger-like with 3 inner setae and 1 distal seta; left exopod 2 segmented, Re1 with distolateral spine and small inner seta, $\operatorname{Re} 2$ with 2 tuberculate finger-like papillae, 1 claw-like process, 2 unequal spines, and inner fringe of hairs.

Remarks: Labidocera kröyeri is readily distinguishable from the other species by the following characteristics: (i) the cephalosome with lateral hooks, (ii) the distal segment of left $5^{\text {th }}$ leg with 2 tuberculated papillae, 1 claw-like process, and 2 unequal spines, (iii) the right posterior corner of prosome bearing 2 unequal processes with a narrow gap between processes. Giesbrecht (1889) described it from the Gulf of Napoli, but his male $5^{\text {th }}$ legs showed minor morphological differences with Indonesian specimens. In Giesbrecht's figures, the left $\operatorname{Re} 2$ has a plumose seta and a nominal seta, while that of the Indonesian specimen has 2 nominal 
setae. L. kröyeri has many variations in the peculiar outgrowths of urosomal somites.

At least five varieties of this species have been described from Indian Ocean, burmanica, bidens, gallensis, similis, and stylifera. L. kröyeri var similis Wolfenden, 1906 is a synonym of L. laevidentata (Brady, 1883), var bidens Krishnaswamy are known from females, var burmanica Sewell, 1912 are known from males, and the rest of two varieties stylifera and gallensis Thompson \& Scott, 1903, were redescribed by Silas \& Pillai (1973) to species.

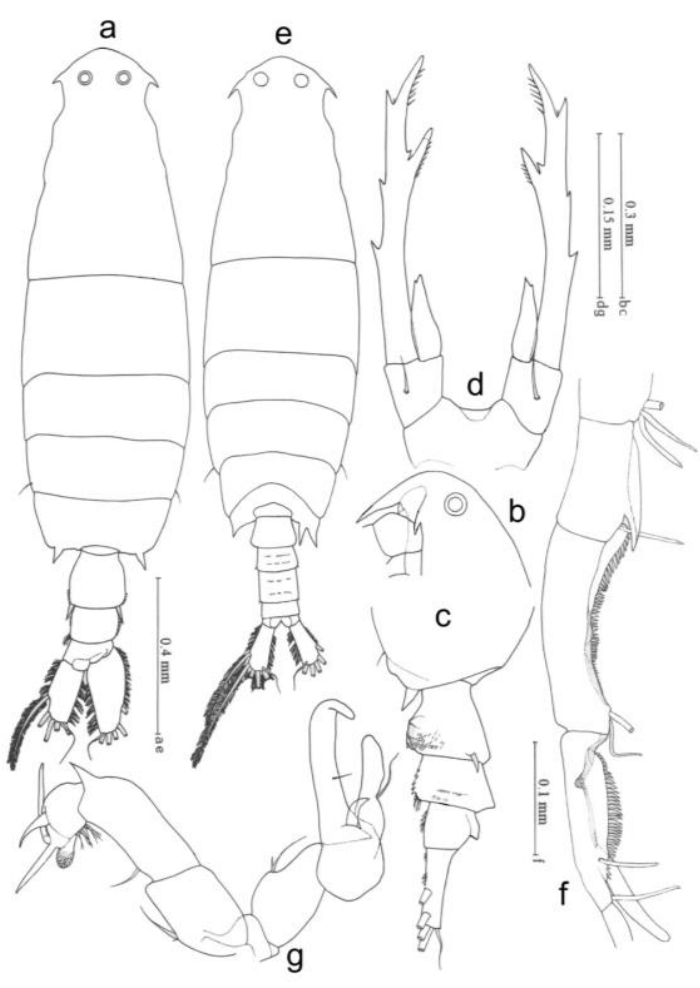

Figure 5. Labidocera laevidentata (Brady, 1883). Female, a, whole animal, dorsal view; b, cephalon, lateral view; c, Pdg5 and urosome, lateral view; d, fifth legs. Male, e, whole animal, dorsal view; f, geniculate region of right $\mathrm{A} 1$; $\mathrm{g}$, fifth legs.

Labidocera laevidentata (Brady, 1883) (Fig. 5) Pontella laevidentata Brady, 1883: 93, p. 38, figs. 1-6 (Type locality: Off Sibago Island, Philippines, single male). Labidocera laevidentata, Giesbrecht \& Schmeil, 1898: 137; A. Scott, 1909: 166, pl. 51, figs. 1-10; Silas \& Pillai, 1973: 789, fig. 11; Greenwood, 1979: 101, fig. 4ae.

Material examined.- Two females $(2.25-2.30 \mathrm{~mm}), 1$ male $(1.90 \mathrm{~mm})$ collected off Kenjeran, Surabaya by surface tow of $0.33 \mathrm{~mm}$ mesh plankton net at daytime on 2 June 1998.

Female.- Prosome cylindrical with cephalic hooks much closer to frontal margin; cephalosome and Pdg1 separated; Pdg4 and Pdg5 fused; posterior corners of prosome directed slightly outwards with acute triangular processes. Cephalosome with pair of small dorsal lenses;
Distribution: Widely recorded from tropical and subtropical Indo-West Pacific (Mori, 1937; Tanaka, 1964). East China Sea (Chen \& Zhang, 1965). Indian Ocean, Australian and Indonesian records given by Sewell (1932), Greenwood (1979) and Scott (1909), respectively.

Previous records of this species from the eastern Pacific (Wilson, 1950) and northwest Atlantic (Giesbrecht \& Schmeil, 1898) were a misidentification.

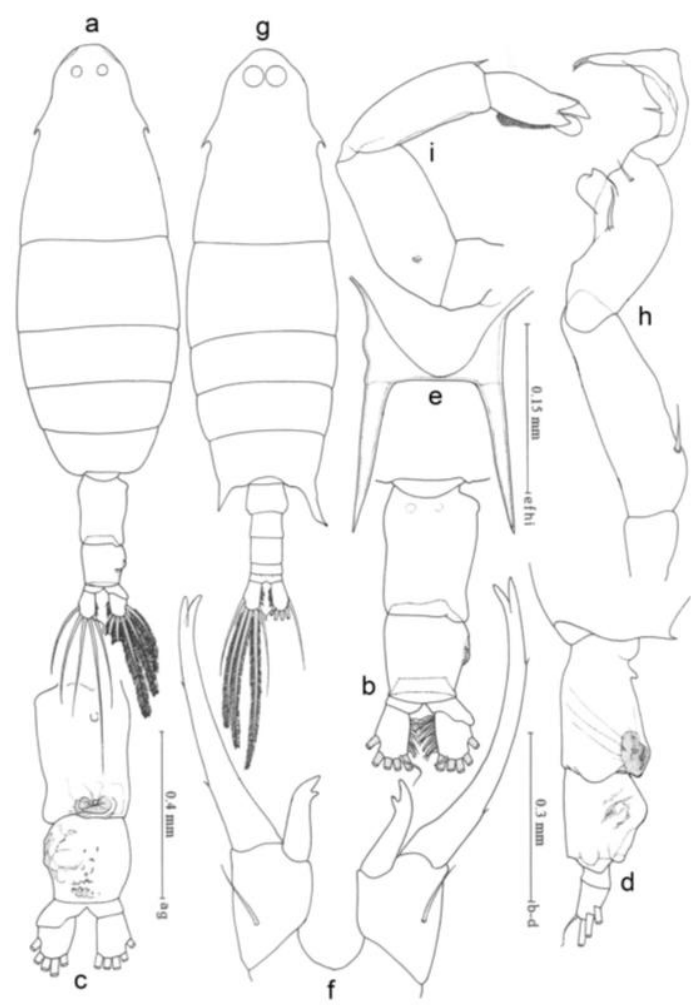

Figure 6. Labidocera minuta Giesbrecht, 1889. Female, a, whole animal, dorsal view; b, urosome, dorsal view; c, urosome ventral view; d, Pdg5 and urosome, lateral view; e, rostrum, anterior view; f, fifth legs. Male, g, whole animal, dorsal view; h, right P5; I, left P5.

rostrum bifid. Urosome consists of 3 somites, genital compound somite asymmetrical, each side with posterolateral spine; Ur2 asymmetrical with ventrolateral surface fringed with closely set spinules; Ur3 asymmetrical, right side shorter than left; caudal rami distinctly asymmetrical, right ramus much broader and longer than left.

Antennule symmetrical, 23 segmented. Fusion pattern and setal formula of antennules same as those of L. acuta. Fifth legs almost symmetrical, exopod uni segmented, curved inwards with 2 outer spinules, 1 strong inner spine and 2 unequal processes at apex, inner margin of inner process with ridge of spinules; endopod with slightly bifurcate tips.

Male.- Cephalon as in female. Posterior corners of Pdg5 noticeably asymmetrical, left side produced into directed and sharp lobe, right side bifurcate and extending 
beyond distal end of Ur1. Urosome consists of 5 somites, Ur2 and Ur3 with dorsal rows of spinules; Ur3 longest; Ur5 shortest; caudal rami somewhat asymmetrical. Right antennule (Fig. 5f) geniculate, indistinctly 14-segmented; Fusion pattern and setal formula of antennules same as those of L. acuta. Segment XIX with short spine-like process posteriorly; segment XX and compound segments XXI-XXIII each with toothed ridge processing comb-like denticles; anterior margin of segment $\mathrm{XX}$ with tooth ridge which extends backs to $1 / 4$ length of posterior segment XIX; segment XXIV with prolonged distally directed, spur-like process posteriorly. Fifth legs (Fig. 5g) uniramous, asymmetrical, basis with outer seta; right exopod 2 segmented, Re1 comprising small palm and elongate thumb, thumb armed with outer seta, outer margin between thumb and distal end of Re1 with 1 large spine-like process; left exopod 2 segmented, Re1 with distolateral spine and 1 outer seta; Re 2 short with 1 distal blunt lamelliform structure crowned with tubercles, and 3 stout spines, middle one curved backwards, inner margin hirsute.

Remarks: The female of $L$. laevidentata is easily identified by the anterior positioning of cephalic hooks, the presence a pair of dorsolateral spines on Ur1, the ventral spinules of Ur2, and the asymmetrical of CR. The male is identified by the rows of dorsal spinules of Ur2 and Ur3 and the form of P5. Brady (1883) has been described this species based on a single male collected off Sibago, Philippines. Scott (1909) transferred L. kroyeri var similis Wolfenden, 1906 to L. laevidentata.

Distribution: Described and most recorded from the Indian Ocean around Maldive and Laccadive Arichipelagoes (Wolfenden, 1906; Silas \& Pillai, 1973). Pacific Ocean: Japanese waters (Matsuo \& Marumo, 1982Australian region: Great Barrier Reef waters (Farran, 1936), Moreton Bay (Greenwood, 1979)

Labidocera minuta Giesbrecht, 1898 (Fig. 6) Labidocera minutum Giesbrecht, 1898: 27, 1892: 446, pls. 16, 35-36, pl. 41, figs. 8, 15, 36 (Type locality: Hongkong). Labidocera minuta Giesbrecht \& Schmeil, 1898: 137; Scott, 1902: 407, 1909: 167; Sewell, 1932: 363; Farran, 1936: 116; Dakin \& Colefax, 1940: 101, fig. 145a-e; Delsman, 1949: 129; Tanaka, 1964: 257, fig. 233; Chen \& Zhang, 1965, pl. 41, figs. 11-16; Saraswathy, 1966: 82; Greenwood, 1979: 101-103, fig. 5a-g; Othman \& Toda, 2006: 310-311, fig. 10.

Material examined.- One female $(1.95 \mathrm{~mm}), 1$ male $(1.75 \mathrm{~mm})$ collected off Kenjeran, Surabaya by surface tow of $0.33 \mathrm{~mm}$ mesh plankton net at daytime on 8 June 1994.

Female.- Prosome (Fig. 6a) elongated; cephalosome and Pdg1 separated; Pdg4 and Pdg5 fused; posterior corner of prosome rounded in dorsal view, but with short ventrally directed process visible in lateral view. Cephalosome anteriorly rounded, with lateral hooks and small pair of dorsal lenses; rostrum bifid, widely spaced and distant from ventral ocelus. Urosome consists of 3 somites; genital compound somite asymmetrical with small processes, one anteroventral and the other posteroventral; anterior and posterior parts of right side swollen; genital operculum loctated ventroposteriorly of midline; right ventral surface of Ur2 with chitinous tubercles which are spread laterally along its right margin; caudal rami asymmetrical, right ramus slightly wider than left one. Fusion pattern and setal formula of antennules same as those of L. acuta. Fifth leg (Fig. 6f) slightly asymmetrical, left leg longer than right; exopod hornshaped with 2 outer spinules and 2 apical processes; endopod bifurcate, inner process shorter.

Male.- Prosome similar to female except for pair of large, contiguous dorsal lenses (Fig. 6g). Cephalosome and Pdg1 separated; Pdg4 and Pdg5 fused; posterior corner of prosome asymmetrical, acutely pointed on left and blade-like on right and longer than left. Urosome consists of 5 somites, genital somite wider than long; caudal rami symmetrical. Fusion pattern and setal formula of antennules same as those L. acuta. Segment XIX with elongated process lying parallel to anterior border of segment and extending to distal border of segment; segment XX and compound segments XXI-XXIII each with toothed ridge; segment XXIV with spur-like process distally. Fifth leg (Fig. 6g, h) uniramous, asymmetrical; right basis with outer seta and patch of inner spinules; right $\operatorname{Re} 2$ segmented. $1^{\text {st }}$ segment comprising palm with bilobed process and 2 setae, $2^{\text {nd }}$ segment elongate, fingerlike, with 1 transparent flap, 3 setae along inner margin, and 2 apical setae; left Re 2 segmented, $1^{\text {st }}$ segment with small distolateral spine, $2^{\text {nd }}$ segment with 2 stout processes, 2 triangular processes, and hirsute inner margin.

Remarks: Labidocera. minuta is closely related to $L$. bengalensis (Silas \& Pillai, 1973), but can be distinguished by the following characteristics. In female, 1 ) the genital compound somite is ca. 1.5 times longer than the $2^{\text {nd }}$ urosomite $(2.5$ times longer in $L$. bengalensis), 2) the Ur2 has prominent chitinous tubercles (no tubercles in L. bengalensis), 3) the CR are asymmetrical (symmetrical in L. bengalensis), and 4) the 5 th legs have a bifurcate endopod (conical $\mathrm{Ri}$ in $L$. bengalensis); in the male, 1) the right posterior process of the prosome extends to the Ur2, and 2) the left 5th leg has 2 pairs of stout processes on the distal segment. Greenwood (1979) described it from Moreton Bay, Australia, but his female figures (see Figs. 5c. g in Greenwood 1979) clearly differ from L. minuta described above. As such, his description must be regarded as $L$. bengalensis. Giesbrecht's figure of L. minuta in 1893 showed minor morphological differences with Indonesian specimens: 1) the anal somite was asymmetrical in Giesbrecht's description, while that of Indonesian specimen is symmetrical, and 2) the right basis of the male P5 has no spinules in the former, while that of latter has a patch of spinules

Distribution: Recorded from tropical and subtropical regions of Indo-Pacific (Sewell, 1947; and records given above). Australian waters records are given by Greenwood (1979). In Indonesian waters recorded by Scott (109) and Delsman (1949), Malaysian coast (Othman et al. 1990), and Malacca Strait (Othman \& Toda, 2006).

Labidocera sinilobata Shen \& Lee, 1963 (Fig. 7) Labidocera sinilobata Shen \& Lee, 1963: 594, figs. 2025; Chen \& Zhang, 1965:42, figs. 8-14; Zheng et. al. 1989. 
Material examined.- Ten females (2.50-2.55 mm), 10 males (2.10-2.15 mm) collected off Kenjeran, Surabaya

by surface tow of $0.33 \mathrm{~mm}$ mesh plankton net at daytime on 10 October 2010.

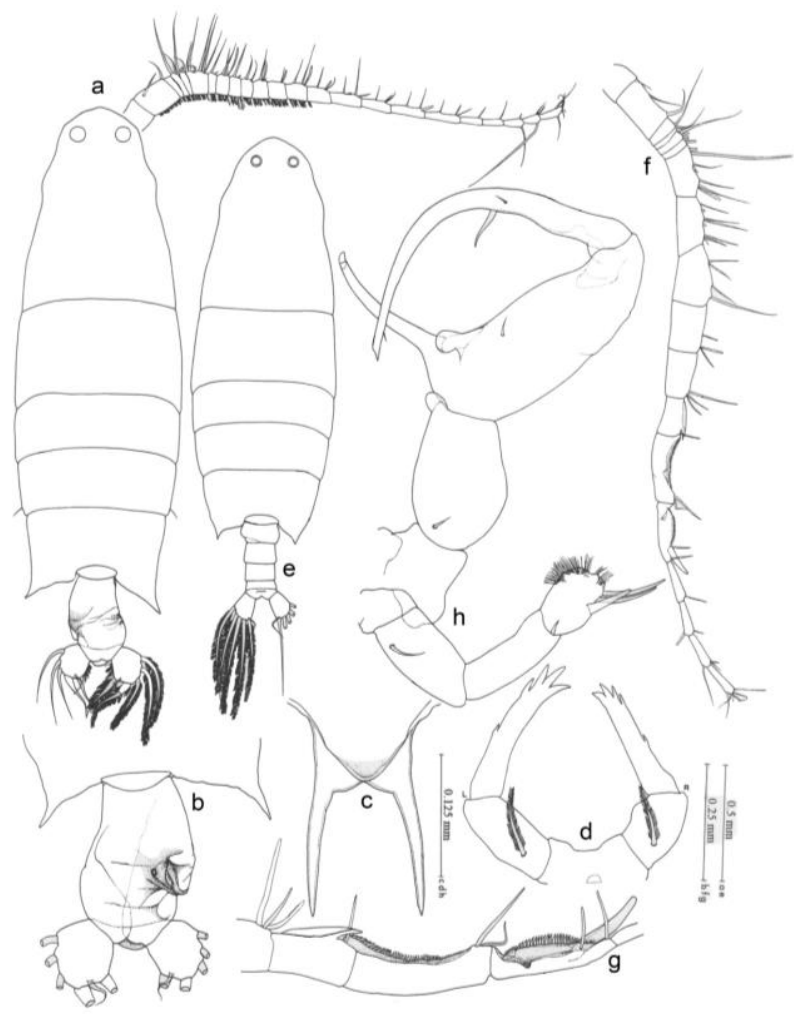

Figure 7. Labidocera sinilobata Shen \& Lee, 1963. Female, a, whole animal, dorsal view; b, Pdg5 and urosome, dorsal view; c, rostrum, anterior view; d, fifth legs. Male, e, whole animal, dorsal view; f, right A1; g, geniculate region of right A1; h, fifth legs.

Female.- Prosome cylindrical without lateral hooks; cephalosome and Pdg1 separated; Pdg4 and Pdg5 fused; posterior corners of prosome produced into asymmetrical strong triangular processes. Cephalosome bluntly rounded anteriorly and with pair of small dorsal lenses; rostrum bifid lying immediately adjacent to ventral ocelus. Urosome consists of 2 somites; genital compound somite asymmetrical, elongated with 1 protruded lobe on left margin; anal somite asymmetrical; caudal rami asymmetrical, fan-shaped, right ramus longer and wider than left, with 5 swollen proximally and 1 small setae, $1^{\text {st }}$ and $2^{\text {nd }}$ innermost setae much thicker than others. Fifth legs asymmetrical, basis with outer seta; basis of left leg slightly longer than right; exopod slightly curved inwards with 1 outer spinule medially and 4 rounded processes at apex; endopod absent.

Antennule symmetrical, 23-segmented. Fusion pattern and setal formula of antennules same as those of L. acuta. Fifth legs (Fig. 7d) uniramous, asymmetrical, left leg longer; coxa and intercoxal sclerite completely fused; basis with outer seta; exopod uni segmented and elongate with 2 outer spinules and 3 unequal apical processes; endopod absent.

Male.- Cephalon as in female except for dorsal eye lenses small. Posterior corners of prosome asymmetrical and ending in sharp processes posteriorly, reaching distal end of Ur1. Urosome consists of 5 somites, naked, genital somite slightly asymmetrical, left margin more convex than right; caudal rami asymmetrical with 5 plumose and
1 small setae. Right antennule (fig. 7f, g) geniculate, indistinctly 15 segmented. Fusion pattern and setal formula of antennules same as those L. acuta. Anterior margin of segment XIX with triangular hooked process posteriorly, extends backwards to $1 / 4$ segment XIX; segment XX with tooth ridge; compound segments XXIXXIII with tooth ridge and prolonged posteriorly into spur-like process.

Fifth legs (7h) uniramous, asymmetrical, basis with 1 proximal outer seta; right leg with short coxa; exopod 2 segmented, Re1 (chela) elongated, thumb elongated, conical, about 0.43 times as long as chela. Outer margin between thumb and distal end of chela with semi-circular lamella arising near base of thumb, and 2 minute setae, one at 1/3 length from proximal end, and another on anterior surface near base of finger; $\operatorname{Re} 2$ (finger) elongated, cylindrical, medially curved inwards and ending in a pointed tip, main curvature at about $2 / 5$ length from proximal end, the direct line length 1.5 times of chela, finger with 1 medial large seta and 2 small setae, 1 at middle and another near apex. Left leg, Re1 as long as basis with 1 small distolateral spine; $\operatorname{Re} 2$ bulb-shaped, with 3 outer unequal round-tipped spines; inner margin hirsute.

Remarks: The present specimen is similar with the descriptions of Shen \& Lee (1963) with additional details presented. Shen \& Lee (1963) described and illustrated briefly this species based on specimens collected from East China Sea. L. sinilobata belongs to the $L$. 
detruncata-group (cf. Fleminger, 1967), which hitherto composed of 10 known species: L. bataviae Scott, 1909; L. caudata Nicholls, 1940; L. cervi Kramer; L. Detruncata (Dana); L. farrani Greenwood \& Othman; L. jaapari Othman, L. madurae A. Scott, L. pavo Giesbrecht and $L$. tasmanica Taw.

Distribution: So far this species was known only from the type locality East China Sea (Chen \& Zhang,

\section{Acknowledgment}

This Study was supported by grants from the Research Center Biology, Indonesian Institute of Sciences (LIPI) and the Japan Society for the Promotion of Science (JSPS: Asian CORE and Core-to-Core Program). Special thanks are due to Nova Mujiono (Research Center for Biology - LIPI) for his help in field sampling.

\section{References}

Brady, G. S. (1883). Report of Science Research 1873-1876. Zoology, 8: $1-142$.

Chen, Q. C. \& Zhang, S. Z. (1965). The plantonic copepods of the Yellow Sea and the East China Sea. I. Calanoida. Studia Marina Sinica, 7: 20-131.

Dakin, W. J. \& Colefax, A. (1940). The plankton of the Australian coastal waters off New South wales. Monogr. Dep. Zool. Univ. Sydney, 1: 1-250.

Dana, J. D. (1847). Conspectus Crustaceorum quae in orbis terrarium circumnavigatione Carlo Wilkes e classe Reipublicae Foederatae Duce, lexit et decripsit J. D. Dana. Proc. American Acad. Arts Sci., 1: 149-1154.

Dana, J. D. (1849). Conspectus Crustaceorum quae in orbis terrarium circumnavigatione Carlo Wilkes e classe Reipublicae Foederatae Duce, lexit et decripsit J. D. Dana. Proc. American Acad. Arts Sci., 2: 9-61.

Dana, J. D. (1852). Crustacea. U. S. Exploring Expedition during the years 1838-1842, under the command of Charles Wilkes. U. S. N. Crustacea, 14(2): 619-1618.

Delsman, H. C. (1939). Preliminary plankton investigations in the Java Sea. Treubia, 17: 139-181.

Delsman, H. C. (1949). Copepods in Sunda Strait. Bijdr. Dierk. 28: 127 132

Farran, G. P. (1936). Copepoda. Scient. Rep. Great Barrier Reef Exped., 5(3): 73-142

Fleminger, A. (1967). Taxonomy, distribution and polymorphism in the Labidocera jollae group (Copepoda: Calanoida) with remarks on evolution within the group. Proc. U.S. Nat. Mus., 120(3567) $1-61$.

Fleminger, A. (1986). The Pleistocene equatorial barrier between the Indian and Pacific Oceans and a likely cause for Wallace's line. UNESCO tech. pap. Mar. Sci., 49: 84-97.

Fleminger, A., B.H.R. Othman \& J.G. Greenwood. (1982). The Labidocera pectinata group: an Indo-West pacific lineage of planktonic copepod with descriptions of two new species. Jour Plankton Res., 4(2): 245-269.

Früchtl, F. (1924). Die Cladoceren- und Copepoden fauna des AruArchipels. Mit Beitragen zur Kenntnis der strukturellen Anomalien indo-pazifischer Plankton-Copepoden. Arb. Zool. Inst. Univ. Innsbruck, 2(2): 1-114.

Giesbrecht, W. (1888). Elenco dei Copepodi pelagic raccoti dal tenente di vascello Gaetano Chierchia durante il viaggio della $\mathrm{R}$. Corvetta "Vettor Pisani" negli anni 1882-1885 e dal tenente di vascello Francesco Orsini nel mar Rosso, nel 1884. Rend. Acc. Lincei. 4(2): 330-338.

Giesbrecht, W. (1889). Elenco dei Copepodi pelagic raccoti dal tenente di vascello Gaetano Chierchia durante il viaggio della $\mathrm{R}$. Corvetta "Vettor Pisani" negli anni 1882-1885 e dal tenente di vascello Francesco Orsini nel mar Rosso, nel 1884. Rend. Acc. Lincei. 5(1): 811-815.

Giesbrecht, W. (1891). Elenco dei Copepodi pelagic raccoti dal tenente di vascello Gaetano Chierchia durante il viaggio della $\mathrm{R}$.
1975; Zheng et al. 1989), off Surabaya (present records), Jakarta Bay, and Flores Sea (Mulyadi unpubl.). $L$. bataviae, L. detruncata, L. madurae and $L$. pavo are widely distributed within the Indo-Pacific region, while $L$. jaapari only known from the type locality, Malacca Strait. The remain 4 species (caudata, cervi, farrani and tasmanica) were recorded only from the Australian region.

Corvetta "Vettor Pisani" negli anni 1882-1885 e dal tenente di vascello Francesco Orsini nel mar Rosso, nel 1884. Rend. Acc. Lincei. 2: 276-282

Giesbrecht, W. (1892). Systematik un Faunistik der pelagischen Copepoden des Golfes von Neapel und der angrenzenden Meeresabshnitte. Fauna und Flora des Golfes von Neapel, Monogr., 19: 1-831.

Giesbrecht, W. \& Schmeil, D. (1898). Copepoda 1. Gymnoplea. Das Tierreich, 6(1-16): 1-169.

Greenwood, J. G. (1978). Two new species of Labidocera (Copepoda: Calanoida) from Queensland. Jour. Nat. Hist. London, 12: 535543.

Greenwood, J. G. (1979). Calanoid copepods of Moreton Bay (Queensland) IV. Family Pontellidae. Proc. Roy. Soc. Queensland, 90: 93-111.

Greenwood, J. G. \& Othman, B. H. R. (1979). Description Labidocera farrani sp. nov. A pontellid copepod known from eastern and northern Australian waters (Crustacea, Copepoda). J. Plankton Res. 1: 231-239.

Huys, R. \& Boxshall, G.A. (1991). Copepod evolution. Ray Soc. Publs. 159: $1-468$

Krämer, A. (1896). Zwei neue Pontella-arten aus Neu-süd Wales. Zool. J. Syst., 9: 720-724.

Krishnaswamy, S. (1952). Some new species of copepods from Madras coast. Rec. Indian Mus., 49: 321-336.

Lubbock, J. (1853). On two new sub genera of Calanoida. Annual Magazine of Natural History, 11(2): 202-209.

Madhupratap, M. \& Haridas, P. (1986). Epipelagic calanoid copepods of the northern Indian Ocean. Oceanologia Acta, 9(2): 105-117.

Matsuo, Y. \& Marumo, R. (1982). Diurnal vertical migration of pontellid copepods in the Kuroshio. Bull. Plankton Soc. Japan, 29: 89-98.

Mori, T. (1929). An annotated list of the pelagic Copepoda from the south-west part of the Japan Sea, with descriptions of two new species. Dobutsugaku Zasshi, 41: 198-212.

Mori, T. (1937). The pelagic Copepoda from the neighbouring waters of Japan. Tokyo: 1-150.

Mulyadi (1997). Three new species of Pontellidae (Copepoda: Calanoida) from coastal waters of Java. Crustaceana, 70(6): 653-675.

Mulyadi (2014). Two new species of the family Pontellidae (Copepoda, Calanoida) from Arguni Bay. Kaimana, West Papua, Indonesia, with notes on their species-groups. Crustaceana, 87(14): 16201639

Nicholls, A. C. (1944). Littoral Copepoda from South Australia. II. Calanoida, Cyclopoida, Notodelphyyoida, Monstrilloida and caligoida. Rec. S. Aust. Mus., 8: 1-62.

Othman, B.H.R., Greenwood, J.G. \& Rothlisberg, P.C. (1990). The copepod fauna of the Gulf of Carpentaria and its Indo-West pacific affinities. Netherlands Journ. Sea Res., 25(4): 561-572.

Othman, B. H. R. \& Toda T., (2006). Pontellid copepods from Singapore. Coastal Marine Science, 30(1): 305-319.

Park, T. S. (1970). Calanoid copepods from the Caribbean Sea and Gulf of Mexico. 2. New species and new records from plankton samples. Bull. mar. Sci., 27: 272-546.

Saraswathy, M. (1966). Pelagic copepods from the inshore waters off Trivandrum coast. Proc. Symp. Crustacea. Mar. Biol. Assoc. India, 1: 74-106.

Scott, A. (1902). On some Red Sea and Indian Ocean Copepoda. Trans. Liverpool Biol. Soc., 16: 397-428.

Scott, A. (1909). The Copepoda of the Siboga Expedition. Siboga Expedition Monograph, 1(29a): 1-323.

Sewell, R.B.S. (1932). The Copepoda of Indian Seas. Calanoida. Memoirs of Indian Musueum, 10: 1-223. 
Shen, C. \& Lee, F. (1963). The estuarine Copepoda of Chiekong and Zaikong Rivers. Acta. Zool. Sin. 8: 177-234.

Silas, E.G. \& Pillai, P.P. (1973). The calanoid copepod family Pontellidae from the Indian Ocean. Jour. mar. biol. Ass. India, 15(2): 771-858.

Tanaka, O. (1964). The pelagic Copepoda of Izu Region, Middle Japan. Systematic Account 12. Families Arietellidae, Pseudocyclopidae, Candaciidae and Pontellidae. Publ. Seto mar. biol. Lab., 12(3): 231-271.

Taw, N. (1974). A new species of Labidocera (Copepoda, calanoida) from Tasmania and its post naupliar developmental stages. Aust. J. mar. freshwat. Res., 25: 261-272.
Thompson, I. C. \& Scott, A. (1903). Report on the Copepoda collected by Prof. Herdman at Ceylon in 1902. Ceylon Pearl Osyter Fisheries. Suppl. Rept., 7: 227-307.

Zheng, Z., Shaojing, L. \& Qiulin, Z. (1989). Copepoda. In: Marine Planktonology. Beijing: China Ocean Press.

Walter, T. C. \& Boxshall, G. A. (2013). World Copepods database. Retrieved from http://www.marinespecies.org/copepoda/.

Wilson, C. B. (1950). Contribution to the biology of the Philippine Archipelago and adjacent regions. Copepoda gathered by the United States Fisheries Steamer "Albatross" from 1887-1909, chiefly in the Pacific Ocean. Bull. U.S. nat. Mus., 100(14): 141441 . 